\title{
EDUCATION OF THE VALUE ATTITUDE IN YOUNGER PUPILS IN THE PROJECT TECHNOLOGY "THE TREE OF LIFE - THE TREE OF GENUS"
}

\author{
Tatiana Hrytsiv \\ Institute of Educational Problems of the National Academy of Pedagogical Sciences of Ukraine \\ 9 Berlinsky str., Kyiv, Ukraine, 02000
}

Solomiia Hrytsiv

Departments modern Ukrainian (Ukrainian Philological Studies and Western European (English))

Taras Shevchenko National University of Kyiv

64/13 Volodymyrska str., Kyiv, Ukraine, 01033

\begin{abstract}
The article is devoted to the actual problem of nurturing the value attitude to the Motherland from younger students by means of folk pedagogy.

The purpose of the article is to substantiate and disclose the project technology "tree of life-tree of the genus", aimed at the cultivation of value relations to the Motherland on the basis of generalized knowledge about the means of folk pedagogy of a younger student.

The complex of the following diagnostic methods was used in the research: interrogation, indirect pedagogical observation, questionnaires, piloting collective and individual conversations, in order to identify the levels of understanding the essence of the value attitude to the Motherland on the basis of folk pedagogy by the cognitive-reflexive criterion.

The scientific approaches (cultural, personality-oriented, competent, activity and system) were determined, the principles and methods on the basis of which the model "Trees of life - trees of the genus" and the project technology of education of value relations to the Motherland by means of folk pedagogy were developed.

A general overview of the tools of folk pedagogy that take place in the project technology is given, their essence and significance are revealed, in the context of which the experience of cultural heritage of the people is transmitted through "spiritual interaction", "dialogical communication" and subject-subject relations with the purpose of upbringing the value attitude towards the Motherland

On the basis of the analyzed curricula, the volume of realization of the sciences that contribute to the education of value relations in the Motherland has been identified.

The main problems of upbringing of value attitudes to the Motherland are determined on the basis of folk pedagogics in the system "tree of life - tree of kind".

According to the author, the introduction of the proposed project technology into the educational process will help to increase the level of national identity and national-cultural identity.

Keywords: education of value attitude to the Motherland, diagnostic methods, folk pedagogics, scientific approaches, national consciousness, national and cultural identity, project technology, subject-subject relations.
\end{abstract}

DOI: $10.21303 / 2504-5571.2020 .001202$

\section{Introduction}

The urgent need for a humanitarian orientation of education is due to a number of reasons, the main ones being globalization processes, the continuous development of technocratic social models, computer science, and economization of politics. It is important for the human community to humanize relationships that are necessary for physical and moral survival, so it becomes clear that there is a need for continuous action in the content of education, not only of the principle of human-centrism, but of cultural-centrism. Culture, which accumulates the life-giving potential of the people, their experience of being and moral values, in its broad sense is the basis of human and society development, is the basis of security of the nation and the state, provides a high national consciousness, is the most powerful factor in the formation of national and cultural identity, promotes upbringing of value relations to the Motherland.

The urgency of the problem is caused by the existing gaps in the national-patriotic upbringing of children on the basis of folk pedagogy, which pose new challenges and require the creation 
of new technologies of the national upbringing strategy in order to bring up value attitudes to the Motherland in a Ukrainian child, starting from younger school age.

According to Behh I.D, in order for a pupil to be oriented to the inner path, which he/she should follow, it is necessary to organize a proper educational process as the basis of his/her spiritually perfect life [1-3].

Therefore, the cross-cutting idea of our educational technology, with the purpose of organizing the educational process in the spiritual aura of the people, is a model of the World tree or a family tree, on the basis of which systematic means of folk pedagogy, which appeal to the education of national consciousness and national-cultural identity, accumulated.

The illustration of the abstract concept of «nationality» through drawing on family metaphors has not gone unnoticed in studies of nationalism and foreign thinkers: both «modernists» like Anderson [4] and «ethosymbolists» such as Smith [5] discuss the existence of «Motherland»or» Fatherland «and the» brotherly «nature of nationality as a demonstration of its deeply affective nature. At the abstract level, the family metaphor extends this logic into the past, hinting to national genealogy: that, if one traces his/her family tree, it will eventually be rooted in pre-modern (ethnic) communities or tribal family sources. The tradition of the «ethnosymbolist» tradition of studying nationalism is predominantly based on this supposition of the ethnic genealogies that are the basic of modern nations. Not surprisingly, the only empirical studies, linking family metaphors and nationality, that the authors know, were conducted by the adherent of «ethnosymbolists», if not «sociobiologists,» of Johnson's nationality concepts. Arguing that presenting the nation or citizens as parents or siblings (for example, the use of «motherland») will be a studied feature of genetic affinity, Johnson links family metaphors to the evolutionary mechanisms of family recognition [6-8].

In encyclopedic literature, both Ukrainian and foreign, the concept of «Motherland», «Fatherland» is presented in several meanings: «Country, in relation to people who were born in it and are its citizens; fatherland, the land of parents (grandparents), the native land»; «Birthplace of anyone»; «Cradle. Place of origination, origin, origin of something « «Heritage from parents. Didizna, patrimony»; «Hereditary estate» [9]. In the explanatory dictionary of the Ukrainian language, the concept of «Matherland» is further elaborated by the following definition: «Property, etc., which passes from the parents, maternity, ancestry, and grandmother» [10].

Accordingly, a national school is based on the educational and cultural traditions of its people, where the concept of «people» (ethnos, nation) is a human community that is different from others by its own identity, separate ethnic territory (Matherland), peculiar language, culture, character, economic life specificity [11].

Modern understanding of ethnology is predetermined by the social order of the state in the field of education and upbringing, which is specified in the State National Program «Education» [12], «Concepts of National Patriotic Education of Children and Youth» [13] «Concepts of civic education of a personality in the conditions of development of the Ukrainian statehood» [14]. The main documents in the field of educational policy on education of the younger generation in the field of science are the National Strategy for the Development of Education in Ukraine [15].

Thus, in the State National Program «Education» (Ukraine of the XXI century), one of the priority directions of reforming education is the formation of national consciousness, love of the native land, education of respect for the Constitution, legislation of Ukraine, state symbols in the youth, instilling a respectful attitude to culture, customs, traditions of all peoples inhabiting Ukraine, education of the spiritual culture of $\phi$ personality, affirmation of principles of universal human morality.

Analyzing the normative base of primary school, we first of all determined that the State standard of elementary general education is designed with the cognitive abilities of young school children and provides for the comprehensive development and upbringing of an individual through the orientation towards the values of the society [16-18].

Based on this methodological point of view, as well as taking care of the national-spiritual revival of Ukraine, the concept of national education for the first time introduced the principle of ethnicization of the educational process, which is an «integral component of socialization of 
children.» This principle is intended to «recreate the mentality of Ukrainian people in children, a «sense of ethnic belonging to Ukrainian people» to perpetuate in the younger generations. This approach promotes education of national consciousness, national-cultural identity, dignity, patriotism and love to the Motherland in children as typical carriers of national culture, continuers of the culture of parents.

According to V. G. Postov, the autochthonousness of Ukrainians is the cornerstone in the study of one's own history, culture, spirituality, establishing which one can build a solid foundation, upbringing unshakable walls of original history, culture, state of Ukraine and raising its children on the basis of humanism [19].

The prominent Ukrainian teacher K. D. Ushinski, who was one of the first to argue for the effectiveness of public education, pays great attention to the study of the problem of forming a holistic picture of the world in students as systematic and holistic ideas about the surrounding world, the basic system of human orientations. The picture of the world, in the sense of K. D. Ushinsky, is the mental model of the world, which is stored in the memory of the people, its history, culture as a systematic representation of the space-time existence of the world, the infinity of the universe and the driving forces of development, place and destination of man in the world [20].

In his turn, Pavlenko Yu. V. in «Prehistory of ancient Rus in the world context» speaks of an image of an eternal tree, in its present deformation, dating back to its prototype to a triplet [21].

One of the most ancient and enduring symbolic elements of understanding the universe in our ancestors is the «tree of life» or the world tree.

Therefore, through the idea of the problem under study, we defined the world tree of life, which embodies the same ancestral tree and is a mental model of the picture of the world in Ukrainians.

Purpose and tasks. The purpose of our study is to substantiate and disclose the project technology «tree of life in the tree of the kin» aimed at the cultivation of value relations to the Motherland on the basis of generalized knowledge about the means of folk pedagogy of a younger student.

\section{Materials and Methods}

To address the objectives of our study, we used a set of diagnostic methods such as surveys, questionnaires, pilot collective and individual interviews, analysis of curricula and textbooks for grades $1-4$. The results of the indirect pedagogical observation, as well as the analysis of the above diagnostic methods have made it possible to determine the levels and indicators of understanding the concept of «generic tree», «tree of life», on the basis of which one can generalize knowledge about the means of folk pedagogy and work out ways of nurturing national consciousness and its identities that provide nurturing of value attitudes towards the Motherland.

At different stages of the study, during the 2017-2018 experiment, 403 students of grades 1-4 were enrolled in the following educational institutions: Rosokhatska Secondary School of Grades I-III of the Chortkiv District of Ternopil Oblast; Gorishno vygnanska NVK I-III degrees of Chortkiv district of Ternopil region; Ternopil Secondary School No. 20; Kryvchesnka Secondary School of Grades I-III of Borshchiv District, Ternopil Oblast; Orynyn secondary school of I-III grades Kamianets-Podilskyi district of Khmelnitsky region; Sofiyivsko-Borschagivsky Educational Complex «Specialized School of Grades-Comprehensive School of Grades», Kyiv. The experimental group (EG) included 104 students of 1-2 grades and 103-3-4 grades, the control group $(\mathrm{KG})-78$ students of $1-2$ grades and $118-3-4$ grades.

\section{Research results}

During the survey and the creative task, conducted after the pilot conversation, the elementary school children had to answer the questions, how they understood the concept of «Motherland», in addition we were interested in how the children understood what a «value attitude» was and how they related it to the real life. It was also important for our study to find out the level of understanding of the concepts of «genus», «family tree», «genealogy», as well as how children are tied to their home, to their home country (small Motherland). 
On the basis of oral questioning and interviewing of 1-2 grades children in our study, during the ascertainment experiment, we determined what knowledge, conception, judgment, conviction or conception of value attitude towards the Motherland they have on the basis of cognitive pedagogy - reflective criterion, which is shown in Table $\mathbf{1 .}$

Table 1

Levels of value attitude towards the Motherland in younger pupils on the basis of folk pedagogy by indicators of cognitive-reflexive criterion (in \%)

\begin{tabular}{|c|c|c|c|c|c|c|c|c|}
\hline \multirow{3}{*}{ Levels } & \multicolumn{4}{|c|}{ Pupils of 1-2 grades } & \multicolumn{4}{|c|}{ Pupils of 3-4 grades } \\
\hline & \multicolumn{2}{|c|}{ KG } & \multicolumn{2}{|c|}{ EG } & \multicolumn{2}{|c|}{ KG } & \multicolumn{2}{|c|}{ EG } \\
\hline & Qty & $(\%)$ & Qty & $(\%)$ & Qty & $(\%)$ & Qty & $(\%)$ \\
\hline High & 6 & 7.7 & 7 & 6.7 & 9 & 7.6 & 8 & 7.8 \\
\hline Sufficient & 23 & 29.5 & 31 & 29.8 & 34 & 28.8 & 30 & 29.1 \\
\hline Average & 27 & 34.6 & 38 & 36.6 & 40 & 33.9 & 35 & 34 \\
\hline Low & 22 & 28.2 & 28 & 26.9 & 35 & 29.7 & 30 & 29.1 \\
\hline Total & 78 & 100 & 104 & 100 & 118 & 100 & 103 & 100 \\
\hline
\end{tabular}

So, in general, we can conclude that parenting of value relations to the Motherland in elementary school by means of folk pedagogy by the cognitive-reflexive criterion is not sufficient, so the need arises in the project technology «The tree of life - tree of kin» in order to thoroughly comprehend the national-cultural identity and need for it - pedagogical experience of Ukrainians as an important factor in fostering the values of patriotism, dignity and love to the Motherland. The tools of folk pedagogy, traditions and norms of folk morality, in the context of which the experience of cultural heritage of the people is transmitted through the system of values, integrate all values of attitude towards the Motherland through «spiritual interaction», «dialogical communication» and subject-subject relations. Thus, the national cultural and historical development is carried out through the spiritual dialogue of generations as an integral part of humanity, the mental model of which is the family tree, which is a cross-cutting idea of our research.

Subject-subject relations are realized in dialogical forms of pedagogical interaction with the help of innovative educational technology of the project with the purpose of creating conditions and realization of scientifically grounded education of value attitude to the Motherland on the basis of folk pedagogy.

In the course of the project activity, younger students comprehend systematic, generalized knowledge about the cultural heritage of the people, acquired over many centuries, which corresponds to the genotypic sources of the development of the psyche of the people of our Motherland, which generalizes the model of life creation of the Ukrainian people, determines the axeological value of the people.

At the design stage, the structure and content of the sequence of educational tasks, the choice of optimal forms and methods for the project implementation, the formation of criteria (emotional-motivational, cognitive-reflexive, activity-acting), their levels (low, sufficient, medium, high), which should be consistent with the goals and principles of the activity itself are defined.

We have developed a project technology of education of the value attitude to the Motherland on the basis of such scientific approaches: cultural, personality-oriented, competence, system and activity.

The cultural approach involves directing all components of education to the culture and an individual as its creator, capable of self-development. Education is considered as a part of a culture that develops and nourishes it. Therefore, in order to ensure that the human values and ideals of culture are recognized by persons, their education must be culturally appropriate [22].

The cultural approach is conditioned by the objective connection of an individual with the culture as a system of values. Thus, the development of culture as a system of values is the development of an individual and its formation as a creative personality [23]. The defining principles of 
cultural studies are the principles of scientific, objectivity, historicism, where the descriptive-empirical method and historical-comparative are widely used.

Following a person-centered approach, the following principles apply: subjectivity, individuality, self-actualization, choice, creativity and success, trust and support, where the following methods are activated: dialogue, game, reflection, facilitation and pedagogical support, diagnosis, creating a situation of success and choice.

The competency approach provides the following principles: the principle of subjective education, the principle of reflectivity, the principle of creativity, efficiency, design and construction of the educational space. These principles are implemented through the following methods: live design, training, business games, reflection, project activity, life situation analysis, targeted creative programs, social practice, creative portfolio.

The following approaches should be considered in the activity approach: subjectivity of education, consideration of leading activities and laws of their change, consideration of sensitive periods of development, determination of the zone of closest development and organization of joint activity of children and adults in it, amplification (enrichment, enhancement, deepening) of children's development, design and creation of the situation of educational activities, the effectiveness of each activity, high motivation of activities, mandatory reflectivity of any activity, with half-life in the organization and management of various activities. This approach involves the use of the following methods: play, student portfolio, reflection, support for initiative, social practice, participation in social projects. The system approach has the following principles: the principle of integrity, the principles of communication, the principle of purposefulness and controllability, the principle of development, the principle of structure.

All of these scientific approaches create the conditions for the implementation of the project technology in order to bring up the value of the attitudes to the Motherland among younger students by means of folk pedagogy.

The cross-cutting idea of this project is a model of the world tree of life, on the basis of which accumulate systematic means of folk pedagogy, which create a holistic understanding of the life-giving of our Motherland by the Ukrainian people and project the education of basic values of love, dignity, patriotism (Fig. 1).

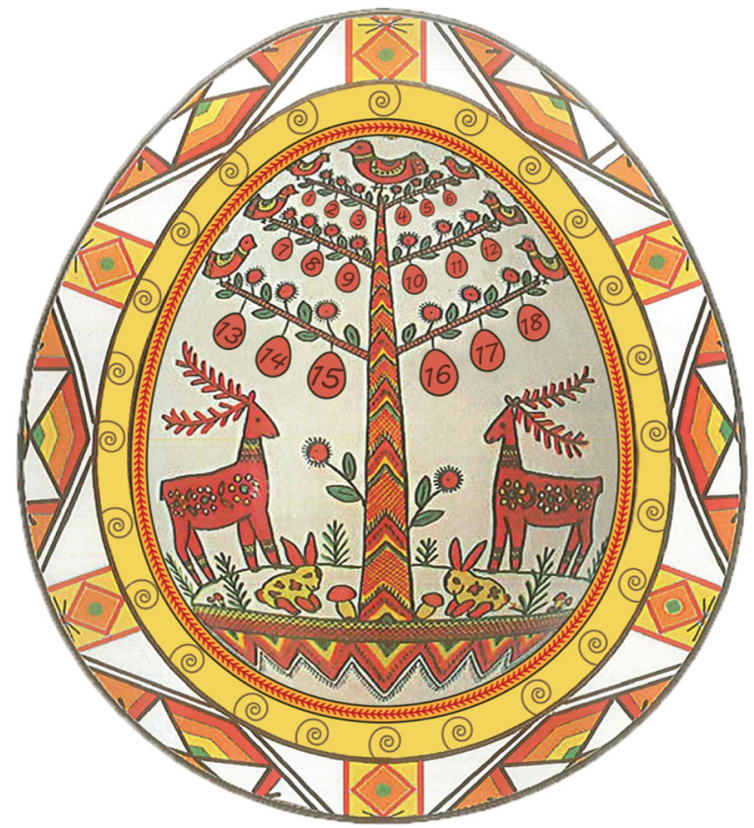

Fig. 1. Model the «Trees of life - the trees of the genus»: 1 - Slippers; 2 - Counters; 3 - Patters; 4 - Counters; 5 - Puzzles; 6 - Provebs; 7 - Sayings; 8 - Parables; 9 - Signs; 10 - Tales; 11 - Legend; 12 - Transfers; 13 - Songs; 14 - Games and fun; 15 - Customs; 16 - Rituals; 17 - Holidays; 18 - Traditio 
Educational ideas and means of folk pedagogy are reflected in folklore, ethnography, ethnology, which contribute to the education of a valuable attitude to the Motherland on the basis of the outlook of the Ukrainian people. Among a huge amount of symbols, signs and image characteristics of the world folklore, one of the most striking, and perhaps the most ancient, is the motif of the World Tree image [24].

The education of a valuable attitude to the Motherland in children of elementary school on the basis of folk pedagogy is realized through awareness of the symbols of the «world tree».

Cognitive information about the customs and traditions of Ukrainians is associated with calendar and ceremonial holidays, arts and crafts and is reflected in the means of folk pedagogy, very conveniently structured on the basis of «tree of the genus-tree of life».

The model of the «World tree» - «The Tree of life is the tree of the genus» in our study systematically accumulates the means of folk pedagogy in order to cultivate a valuable attitude to the Motherland, as «... cradle. Places of origin, occurrence of something» «Heritage from parents. Ancestry, patrimony; Hereditary estate».

In project technology, a systematic approach generalizes a disparate understanding of the means of oral folk art through language, as a code of the nation, outlining all the vital stages of being Ukrainian.

Thus, our proposed educational technology on the theme «My Motherland» is structurally calculated for four weeks, where, based on the above principles and methods, the educational activity is carried out with the help of folk pedagogy.

Important for our work were research on the tools of folk pedagogy of natural scientists $\mathrm{G}$. Volkov [25], O. Leonova [26], M. Stelmakhovich [27], A. Orlov [28] and others.

Therefore, an important way to reform the education system is to restore the educational potential of folk pedagogy and, at the same time, to introduce new forms and methods that would serve the main purpose of the problem namely: inheritance of the spiritual heritage of the Ukrainian people, the acquisition of the social experience by the young generation on the basis of the educational practice of the Ukrainian people, the achievement of a high culture of interethnic relations, the development of spirituality, the formation of personal and civic traits in younger students - love, dignity, patriotism .

In the context of the above, there is an urgent need for the development and testing of a experimental approach to home-schooling of young children at the experimental level.

During the first week, the theme «From the native lighthouse, the light of ancestors pours», stimulated by the project work with the help of various forms and methods, work on education of value relations to the Motherland through tales, sayings, proverbs, riddles, songs. The understanding of the meaning of the «spoken word» was built not only as an influence on the emotional sphere of a child's personality, but also a conceptual one, which carries a certain understanding; knowledge there is already a cognitive sphere.

Among the most archaic folk knowledge, reflected in the means of folk pedagogy, one of the foremost places belongs to folk mythology and, in particular, to cosmogony, where much of the primordial myths are encoded in the Ukrainian fairy tale. The fairy tales reveal many elements of national rituals, customs and beliefs, which underline the profound level of the worldview of Ukrainians [29-31].

The fairy tale, according to the testimony of G. Volkov [25], O. Leonova [26], G. Lunina [32], Ye. Siavavko [33] and other researchers, as the most widespread type of oral folk art, is a powerful educational tool.

According to the general classification, fairy tales are divided into fantastic, about animals, social and household. In the project technology, we used the basic elements and images of cosmogonic ideas about the universe in fairy tales, which bear the idea of:

a) a world tree («Ivasik-Telesik»);

b) an image of an egg («About grandfather, grandmother and little hen»);

c) the image of a snake («Pokotygoroshko»);

d) the mythology of water («Ivan the prince and the iron wolf»);

e) a stone in the creation of the world («About the hero John the Sukhobrozdenko and Nastya the Beautiful»). 
In order to form a holistic understanding of the means of folk pedagogy in the project work of the first week on the theme «Father's right word», the educational work was carried out with the assimilation of slippers, pistachios, cozies, entertainments, counters, patters, counters, funny folk songs for children, developed a space-hour view of the world.

In our study with elementary school students we used puzzles that were related to the concept of «world tree»: «Oak-oak long age, it has 12 branches, each branch has four nests, and which has 7 simple eggs and each the name is» [34]. The riddle is one of the oldest genres of folk art by origin [35]. The specificity of the mysteries is that they are encrypted in an allegorical form of an object or phenomenon and you need to find its original meaning.

In short utterances - proverbs and sayings, which are the means of folk pedagogy, the educational experience of the people is expressed. In the upbringing of elementary school students, proverbs are used to explain the content and illustrate the rules of a culture of behavior that express the instructive experience of the people.

They act as a means of influencing the child's consciousness in the form of a kind of hint and instruction, as well as stimulate reflection, self-affirmation, revealing personality traits, evaluating a person, his/her actions, pointing to the positive or negative traits of the child, without affecting feelings of dignity. G. Volkov [25], M. Stelmakhovich [27], E. Siavavko [33] stated that people associated sayings, proverbs with names. Our ancestors lived according to the calendar pages of the annual cycle of national holidays, were able to record changes in nature, predict the weather and temperature phenomena and their influence on the biological rhythm of life.

Our design technology is built on this principle of our nation's life, showing how it is clearly and firmly established in folk pedagogy, including riddles, proverbs, sayings, beliefs, songs, games, holidays, customs and traditions.

The people's life is closely linked to the rites. They are most fully preserved in such pedagogical means as songs, dating back to ancient times. Among all genres of Ukrainian folklore, the spring story is characterized by the greatest variety of subjects. Based on the reasonable division of nuts into the old and the newest layers by A. Holubets [36] we distinguished the following ancient motives in the burners, recorded at S. Hrytsiv in Ternopil: cosmogonic, vegetative-economic, love-marriage.

In addition, in our study, there are songs of the winter holidays (carols and generosities), songs of the summer cycle (The Trinity, Kupala songs, Peter's songs) and lulls as a separate kind of oral folk art.

In the second week of the project «Father's Day», we used the following tools of folk pedagogy in order to bring up value attitudes towards the Motherland: folk games, customs, traditions, holidays, rituals; elements of arts and crafts, including embroidery symbolism.

In the third week of the project technology on the theme «Blessed kin that gives roots and wings» for children such means of folk pedagogy as elements of family and everyday culture (phenomena of nature, objects of everyday life, set of educational ideas, native language, native history the nature of the native land), folk calendar and tree symbolism) were used. Each week provides a practical experience for project participants, which they and their teacher determine together according to each topic of the lesson.

During the fourth week, the systematization of the acquired knowledge is carried out, where project participants create a flybook on the basis of the model «Tree of life - tree of kin», fixing in it their own understanding, judgments, knowledge, conception of value attitude to the Motherland on the basis of folk pedagogy.

Reflection is the education of the value attitude of love, dignity, patriotism to the Motherland on the basis of the means of folk pedagogy. Project participants defend their own projects.

Thus, the use of new innovative educational technologies, in particular, the design ones, confirmed that they are effective in nurturing valuable attitudes towards the Motherland among younger students on the basic of folk pedagogy.

\section{Discussion}

The goals and objectives of educational programs are implemented by textbooks and manuals. We have tried to analyze that elementary school children, through educational programs by 
state standart [18] and textbooks, can know about the Motherland through folk pedagogy, as it is the basis for the upbringing of values and is a cognitive component of our study.

We found identical research in K. D. Shevchuk [37] from the topic "Formation of value attitude towards the native land in younger students", where the analysis of a textbook content is almost identical in percentage, but we have higher indicators because of the educational material, which introduces much more children of primary school age to their homeland.

In addition, we tried to consider the textbooks for the 1st form according to the updated programs and identified in their content a significant part of the topics of the scientific direction in the educational branch: «Language and Literature» «Bukvarik» for the 1st class ( 2 part), edited by Vashulenko M. S., Vashulenko A. In [38] that as a percentage is $26 \%$ of the textual material; in the integrated textbook «I am exploring the world» (2 part), edited by Grushchynska I., Khytra Z., Drobiazko I., [18], which is $10 \%$ of the educational material, built thematically by weeks; in the textbook of the integrated course for the 1st form «Art», by Ruble T. E., Shcheglova T. L., Med I. L., [39], which is $32 \%$ of the program material in the field of science.

Therefore, the programs of the New Ukrainian School integrate science materials into educational subjects, but not enough. Therefore, there is a need for a separate subject - a natural sciences, which would wholly nurture values of the homeland and have a national orientation, given that the elementary school lay the foundation of national outlook and national and cultural identity.

Comparing the levels of value attitudes towards cognitive performance in younger students according to cognitive criteria in O. P. Tretyak [40] with our research, it should be noted, that we support the view that children in grades 3-4 compared to students 1-2-grade have more formed ideas and knowledge about value attitudes both to the person and to the Motherland, can express their opinions on this issue better, have certain beliefs, which is explained by their age peculiarities and results of education and upbringing in primary school.

But we found at diagnosis that the average level of knowledge is higher than low, due to the fact that elementary school children in the course of studying a number of subjects of the current programs become acquainted to some extent with the topics of science content that contain knowledge about the Motherland on the basis of folk pedagogy. Accordingly, in our research, we set ourselves the goal of working to raise sufficient and high levels of nurturing value attitudes towards the Motherland.

The effectiveness of the experimental work is evidenced by the quantitative and qualitative changes in indices of education of the value attitude to the Motherland by the cognitive-reflexive criterion, presented in Table 2.

Table 2

Dynamics of levels of upbringing of the value attitude to the Motherland in younger students by the cognitivereflexive criterion

\begin{tabular}{|c|c|c|c|c|c|c|c|c|c|c|c|c|}
\hline \multirow[b]{3}{*}{ Levels } & \multicolumn{4}{|c|}{ Control group } & \multirow{2}{*}{\multicolumn{2}{|c|}{ Dynamics }} & \multicolumn{4}{|c|}{ Experimental group } & \multirow{2}{*}{\multicolumn{2}{|c|}{ Dynamics }} \\
\hline & \multicolumn{2}{|c|}{ At the beginning } & \multicolumn{2}{|c|}{ At the end } & & & \multicolumn{2}{|c|}{ At the beginning } & \multicolumn{2}{|c|}{ At the end } & & \\
\hline & 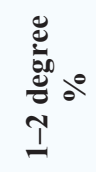 & 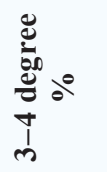 & 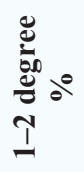 & 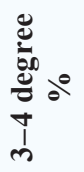 & 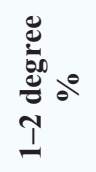 & 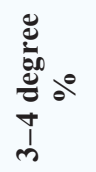 & 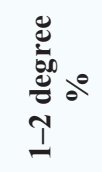 & 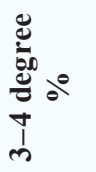 & 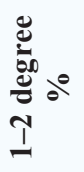 & 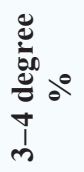 & 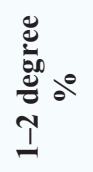 & 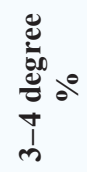 \\
\hline High & 7.7 & 7.6 & 20.5 & 21.1 & $\begin{array}{c}+12.8 \\
17.0\end{array}$ & +13.5 & 6.7 & 7.8 & 18.3 & 17.5 & +11.6 & +9.7 \\
\hline Sufficient & 29.5 & 28.8 & 44.9 & 45.8 & +15.4 & +17.0 & 29.8 & 29.1 & 44.2 & 40.8 & +14.4 & +11.7 \\
\hline Average & 34.6 & 33.9 & 21.8 & 20.3 & -13.6 & -14.0 & 34.0 & 34.0 & 25.0 & 24.2 & $\begin{array}{c}-11.0 \\
-0\end{array}$ & -9.8 \\
\hline Low & 28.2 & 29.7 & 12.8 & 12.7 & -14.6 & -17.0 & 26.9 & 29.1 & 12.5 & 17.5 & -14.4 & -11.6 \\
\hline
\end{tabular}




\section{Conclusion}

Thus, in primary school, according to the State standard of the current programs of education of the value attitude to the Motherland by means of folk pedagog, it is not enough. According to the results of our study, young children of school age do not have a complete systematic understanding of the interdependent connections between the concepts I - family family - gender - nation - Motherland - Creator of the Universe, which is clearly expressed in the educational system of folk pedagogy. Therefore, the project technology «My Motherland», the cross-cutting idea of which is the world tree of life - the tree of the genus, generalizes disparate knowledge, ideas, judgments, understanding into a certain system of world knowledge about the Motherland, which significantly increases the level of national-cultural identity. The solution of the problem under investigation is evidenced by the dynamics of high and sufficient levels increase by the cognitive-reflexive criterion.

\section{References}

[1] Johnson, G. R. et. al.; Reynolds, V. et. al. (Eds.) (1987). The evocative significance of kin terms in patriotic speech. The Sociobiology of Ethnocentrism: Evolutionary Dimensions of Xenophobia, Discrimination, Racism and Nationalism. London: Croom Helm.

[2] Lauenstein, O., Murer, J. S., Boos, M., Reicher, S. (2015). “Oh motherland I pledge to thee ...”: a study into nationalism, gender and the representation of an imagined family within national anthems. Nations and Nationalism, 21 (2), 309-329. doi: http:// doi.org/10.1111/nana.12123

[3] Bekh, I. D. (2004). Vykhovnyi protses v osiahnutykh hlybynakh. Shkilnyi svit, 5, 3-41.

[4] Anderson, B. (1983). Imagined Communities: Reflections on the Origins and Spread of Nationalism. London: Verso, 160.

[5] Smith, A. D. (1996). Culture, community and territory: the politics of ethnicity and nationalism. International Affairs, 72 (3), 445-458. doi: http://doi.org/10.2307/2625550

[6] Johnson, G. R. (1986). Kin Selection, Socialization, and Patriotism: An Integrating Theory. Politics and the Life Sciences, 4 (2), 127-140. doi: http://doi.org/10.1017/s0730938400004676

[7] Johnson, G. R. (1987). In the Name of the Fatherland. International Political Science Review, 8 (2), 165-174. doi: http:// doi.org/10.1177/019251218700800207

[8] Johnson, G. R.; James, P., Goetze, D. (Eds.) (2001). The roots of ethnic conflict: an evolutionary perspective' in Evolutionary Theory and Ethnic Conflict. Westport, CT: Praeger, 19-38.

[9] Yaremenko, V., Slipushko, O. (1999). Novyi slovnyk ukrainskoi movy. Vol. 1. Kyiv: AKONIT, 98.

[10] Kalashnyk, V. S. (Ed.) (2001). Tlumachnyi slovnyk ukrainskoi movy. Kharkiv: Prapor, 992.

[11] Zalizniak, L. (1996). Istorychni vytoky ukraintsiv. Istoriia v shkoli, 1, 48.

[12] Pro derzhavnu natsionalnu prohramu «Osvita» (Ukraina 21 stolittia) (1993). Postanova Kabinety ministriv Ukrainu No. 896. 03.11.1993. Available at: https://zakon.rada.gov.ua/laws/show/896-93- \%D0 \%BF

[13] Concept of national patriotic education of children and youth (2015). Informatsiinyi zbirnyk ta komentari Ministerstva osvity i nauky Ukrainy, 8, 87-95.

[14] Kontseptsiia hromadianskoho vykhovannia osobystosti v umovakh rozvytku ukrainskoi derzhavnosti. Proekt (2001). Informatsiinyi zbirnyk Ministerstva osvity i nauky Ukrainy.

[15] Natsionalna stratehiia rozvytku osvity v Ukraini na period do 2021 roku (2013). Ukaz Prezydenta Ukrainy No. 344. 25.06.2013. Available at: https://pon.org.ua/novyny/2446-nacionalna-strategiya-rozvitku-osviti-v-ukrayini.html

[16] Grinchenko, B. D. (1896). Etnografyicheskie materialyi, sobranyie v Chernigovskoy i msosednih s ney guberniyah: Rasskazyi, skazki, predaniya, poslovitsyi, zagadki i pr. Vol. 2. Chernigov: Tipografiya Gubernskogo Zemstva, 390.

[17] Hrushchynska, I., Khytra, Z., Drobiazko, I. (2018). Ya doslidzhuiu svit. Pidruchnyk intehrovanoho kursu dlia 1 klasu zakladiv zahalnoi serednoi osvity. Kyiv: Orion, 111, 115.

[18] Derzhavnyi standart pochatkovoi zahalnoi osvity (2011). Ofitsiinyi visnyk Ukrainy, 33, 1378.

[19] Postovyi, V. H. (2012). Ethnogeneses and Ethnopedagogics of Ukrainian Family in the Context of Global Peripeteia of Modern Days. Pedahohichnyi dyskus, 13, 284-291.

[20] Medvedeva, N. G. (2009). Formirovanie tselostnoy kartinyi mira u rebenka na nachalnoy stupeni obrazovaniya v pedagogicheskoy sisteme K. D. Ushinskogo. Kursk, 25.

[21] Pavlenko, Yu. V. (1994). Peredistoriia davnikh rusiv u svitovomu konteksti. Kyiv: Feniks, 398.

[22] Goryachko, E. S. (2014). The Tradition in the Cultural Space: the Paradigms of the Research. Izvestiya Saratovskogo universiteta. Novaya seriya. Seriya «Filosofiya, psihologiya, pedagogika», 14 (3), 18-21. 
[23] Boichuk, Yu. D. (2009). Kulturolohichnyi i aksiolohichnyi pidkhody do formuvannia ekoloho valeolohichnoi kultury studentiv pedahohichnykh navchalnykh zakladiv. Visnyk NTUU «KPI». Seriia «Filosofiia. Psykholohiia. Pedahohika», 3, $121-125$.

[24] Mishchenko, A. (2010). Uiavlennia ukraintsiv pro svitove derevo u porivnialnomu konteksti. Etnichna istoriia narodiv Yevropy, 31, 47-54.

[25] Volkov, H. N. (2000). Yetnopedahohyka. Moscow: Akademyia, 176.

[26] Leonova, O. V. (1996). Razvitie nravstvenno-volevyih kachevstv lichnosti starshego doshkolnika sredstvami narodnoy pedagogiki. Stavropol.

[27] Stelmakhovych, M. H. (1997). Ukrainska narodna pedahohika. Kyiv: IZMN, 323.

[28] Orlova, A. P. (1982). Progressivnyie idei i opyit narodnoy pedagogiki v uchebno-vospitatelnoy rabote shkol Belorussii 19171941 gg. Moscow.

[29] Pro Stratehiiu natsionalno-patriotychnoho vykhovannia ditei ta molodi na 2016-2020 roky (2015). Ukaz Pryzydenta Ukrainy No. 580/2015. 13.10.2015. Available at: https://www.president.gov.ua/documents/5802015-19494

[30] Prokopova, O. P. (2005). Metodyka vyvchennia ukrainskoi narodnoi kazky z oporoiu na rozkryttia yii kosmohonichnoho pokhodzhennia. Kyiv.

[31] Chumarna, M. I. (1994). Mandrivka v ukrainsku kazku. Lviv: Kameniar, 78.

[32] Lunina, G. V. (2004). Vospitanie detey na traditsiyah russkoy kulturyi culture. Moscow: TsGL, «ELIZE TREYDING», 242.

[33] Siavavko, Ye. (1974). Ukrainska etnopedahohika v yii istorychnomu rozvytku. Kyiv: Naukova dumka, 149.

[34] Grinchenko, B. D. (1895). Etnografyicheskie materialyi, sobranyie v Chernigovskoy i msosednih s ney guberniyah: Rasskazyi, skazki, predaniya, poslovitsyi, zagadki i pr. Vyp. 1. Chernigov: Tipografiya Gubernskogo Zemstva, 308.

[35] Zahadky (1962). Seriia «Ukrainska narodna tvorchist». Kyiv: Vyd-vo AN URSR, 512.

[36] Holubets, O. (2003). Khrystyianski motyvy v haivkakh. Narodoznavchi zoshyty, 1-2, 51-54.

[37] Shevchuk, K. D. (2009). Formuvannia u molodshykh shkoliariv tsinnisnoho stavlennia do ridnoho kraiu. Kyiv.

[38] Vashulenko, M. S., Vashulenko, O. V. (2018). Ukrainska mova. Bukvar. Kyiv: Vydavnychyi dim «Osvita», 112.

[39] Rublia, T. Ye., Shchehlova, T. L., Med, I. L. (2018). Mystetstvo. Pidruchnyk intehrovanoho kursu dlia 1 klasu zakladiv zahalnoi serednoi osvity. Kharkiv: Ranok, 114.

[40] Tretiak, O. P. (2014). Vykhovannia tsinnisnoho stavlennia do liudyny u molodshykh shkoliariv u navchalno-vykhovnomu protsesi. Kyiv, 209. 